\title{
Predicting Mass Transfer Extraction with Steam Flow, Applying Boundary-Layer Concepts
}

\section{Jose Antonio Rocha-Uribe ${ }^{1 *}$, Laura Catalina Soto-Armenta ${ }^{2}$, Alfredo Raul Hernandez-Ruiz ${ }^{1}$, Jorge Ciro Jimenez-Ocaña ${ }^{3}$}

${ }^{1}$ Colegio de Bachilleres de Chiapas, Tuxtla Gutiérrez, Mexico

${ }^{2}$ Campus Merida, Universidad del Valle de Mexico, Mérida, Mexico

${ }^{3}$ Instituto Tecnológico de Tuxtla Gutiérrez, Tuxtla Gutiérrez, Mexico

Email: *antonio.rocha@uady.mx

How to cite this paper: Rocha-Uribe, J.A. Soto-Armenta, L.C., Hernandez-Ruiz, A.R. and Jimenez-Ocaña, J.C. (2021) Predicting Mass Transfer Extraction with Steam Flow, Applying Boundary-Layer Concepts. Journal of Materials Science and Chemical Engineering, 9, 46-58.

https://doi.org/10.4236/msce.2021.96004

Received: May 26, 2021

Accepted: June 27, 2021

Published: June 30, 2021

Copyright $\odot 2021$ by author(s) and Scientific Research Publishing Inc. This work is licensed under the Creative Commons Attribution International License (CC BY 4.0).

http://creativecommons.org/licenses/by/4.0/

\begin{abstract}
Theory and concepts of boundary layer mass transfer is applied to correlate experimental data on extraction of essential oils from vegetable leaves and stems, using steam. From these theory, concepts and experimental data with seven systems, two correlations are developed to predict the Sherwood number and mass transfer coefficient as function of Reynolds and Schmidt numbers. From these equations, the molar flux, the amount of solute extracted, and the yield of extraction is predicted. A steam of higher temperature normally improves the mass transfer and the yield. A method to estimate the enhancement for temperature increase is proposed. The correlations developed are applied to a case with industrial size that was no part of the data for correlation generation. Theory may be applied for industrial applications.
\end{abstract}

\section{Keywords}

Boundary Layer, Essential Oil, Extraction, Yield, Steam Distillation, Mass Transfer Coefficient

\section{Introduction}

Essential oil from plants is used in food, pharmacy, and fragrance industries due to their organoleptic and biological properties associated with their natural characteristics. Leaves and stem from plants are the raw material for the extraction of the essential oil. The total extraction of essential oil from vegetal leaves is usually small than 5\% and there are several methods to perform the extraction. Hydro distillation with water in contact with the plant [1], steam distillation, with steam (but not water) contacting the plant, mechanical pressure (squeezing) [2], soxh- 
let extraction with organic solvents [3], extraction with supercritical solvents like $\mathrm{CO}_{2}$, and microwave extraction [4].

The extraction of essential oil by steam distillation uses a cylindrical column filled with vegetal leaves and stems. The steam flow through the leaves and stems, first heating them and then dissolving on it the essential oil, and taking out from the column with the flowing steam. The flowing steam that leaves the column is passing to a condenser where the oil and water usually form two different liquid phases and are separated in equipment called Florentine. Figure 1 shows a scheme of a steam distillation system and a typical diagram from experimental results taken from Cerpa's Dissertation [5].

The experimental data of yield versus time of Figure $1(b)$ is modeled, by example with Xavier et al. [6] approach, using the mechanistic model proposed by Cerpa, Mato and Cocero [7], or some other.

In this manuscript, the final yield is modeled by using the concepts of boundary layer that were developed first for fluid flow by Ludwig Prandtl in 1904 who develop the first differential equations to model the hydraulic phenomena. Blausius helps to solve the mathematical model. Prandtl and other researchers began to apply it to heat transfer, Chilton-Coulburn and Guilliland-Sherwood applied it to mass transfer. Latter Bird Stewart and Lightfoot developed the concept of transport phenomena. This lead to apply the boundary layer theory to experimental and industrial cases, help the field of applied chemistry to be converted on chemical engineering and get maturity as science and engineering.

Chemical engineering applies the boundary layer concepts to correlate experimental data on flow of fluids, heat transfer, and mass transfer, as function of dimensionless numbers.

For mass transfer: Reynolds $R e=\frac{U_{e f} \rho_{V} D_{c}}{\mu_{V}}$, Schmidt $S c=\frac{\mu_{V}}{\rho_{V} D_{A B}}$, and Sherwood $S h=\frac{k_{C} D_{C}}{D_{A B}}$. Basically:

$$
S h=\alpha_{1} R e_{D c}^{\alpha_{2}} S c_{V}^{\alpha_{3}}
$$

Several series of experimental and reported data is used to get variation on

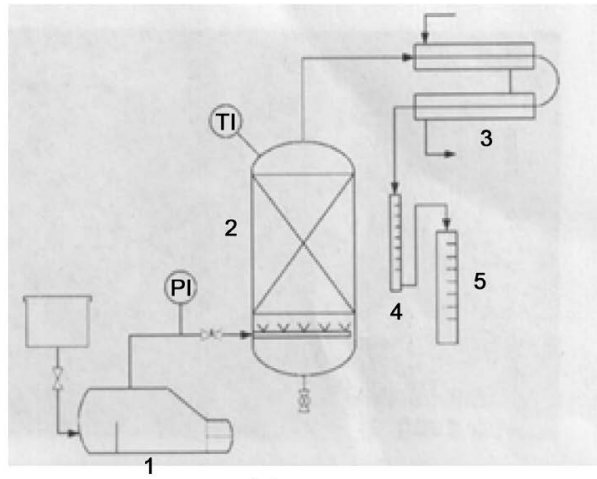

(a)

\section{CERPA 2007, P 9}

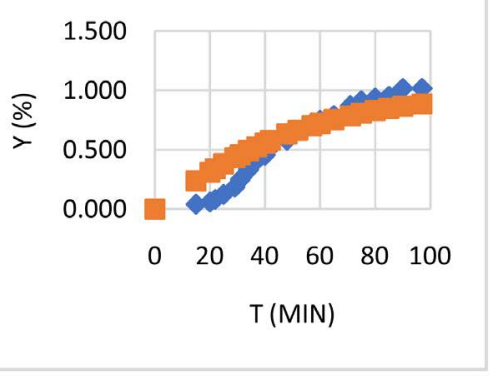

(b)

Figure 1. (a) Scheme of steam extraction system, (b) Yield of extraction versus time. 
operational, physical properties, and geometrical parameters, to generate correlations to predict Sherwood number., and to calculate mass transfer, and yield of extraction.

\section{Materials and Methods}

\subsection{Experimental Reported Data Used}

Table 1 shows the systems used.

\subsection{Boundary Layer Concept Applied to Mass Transfer}

(Taken from [8]) A concentration gradient is formed together to the hydrodynamic and thermal one. Let $C_{A O}$ be the concentration of the incoming flow to a plate made of a solid that is soluble in the liquid. $C_{A O}$ will be the concentration also at core of the flow, far from the plate. When the liquid is in contact with the plate the equilibrium is reached instantaneously at the interface liquid-solid. The concentration of $A$ at the fluid, at the plane of contact with the solid surface will be that of saturation $\left(C_{A s}=C_{A i}\right)$. The mass molecular diffusion at y direction will set that the concentration gradient be growing when the liquid advance in $x$.

Authors or researchers from Table 1, report the dynamic (yield versus time). In this study only the final yield is correlated with physical properties, geometrical characteristics, and operational parameters. Defining the variable $\gamma=C_{A i}-C_{A}$ (analogous to temperature in excess), the concentration gradient will be that of Figure 2. The dotted line is laminar underlayer.

The edge of the concentration boundary layer is then the geometric place where $\gamma_{A}=0.99 \gamma_{A o}$, being $\gamma_{A o}=C_{A i}-C_{A o}$ the maximum value de $\gamma$.

Table 1. Characteristics of the studied systems.

\begin{tabular}{|c|c|c|c|c|c|c|}
\hline Author(s) & Journal & Plant & Solute & $\mathrm{Dc}(\mathrm{m})$ & $\mathrm{Zc}(\mathrm{m})$ & $\mathrm{Q}_{\mathrm{V}}(\mathrm{L} / \mathrm{h})$ \\
\hline $\begin{array}{l}\text { Cerpa et al. 2007, } \\
2008 \text { [5] [7] }\end{array}$ & $\begin{array}{l}\text { Ph.D. (2007) } \\
\text { Dissertation, } \\
\text { AIChE J. 2008 }\end{array}$ & Lavender & $\begin{array}{l}\text { Linalool and } \\
\text { linalyl acetate }\end{array}$ & 0.35 & 0.42 & $0.6-2.10$ \\
\hline $\begin{array}{l}\text { Masango, } 2005 \\
{[9]}\end{array}$ & $\begin{array}{l}\text { J. of Cleaner } \\
\text { Production }\end{array}$ & Artemisia & Camphor-L & 0.09 & 0.34 & $0.15-1.19$ \\
\hline $\begin{array}{l}\text { Soto-Armenta } \\
\text { et al. } 2017 \text { [10] }\end{array}$ & $\begin{array}{l}\text { J. of Essential Oil } \\
\text { Bearing Plants }\end{array}$ & $\begin{array}{l}\text { Lippia } \\
\text { graveolens } \\
\text { (oregano) }\end{array}$ & $\begin{array}{l}\text { Carvacrol } \\
\text { and Thymol }\end{array}$ & 0.10 & 0.76 & $1.4-6.98$ \\
\hline $\begin{array}{l}\text { Malekydozzadeh, } \\
2012[11]\end{array}$ & $\begin{array}{l}\text { Iranian J. of } \\
\text { Chem. Eng. }\end{array}$ & Rosemary & $\begin{array}{l}\text { a-pynene, } \\
\text { 1, } 8 \text { Cineole, } \\
\text { Camphor }\end{array}$ & 0.06 & 0.20 & $240-420$ \\
\hline $\begin{array}{l}\text { Roautby et al. } \\
2007 \text { [12] }\end{array}$ & $\begin{array}{l}\text { J. of food } \\
\text { Engineering }\end{array}$ & Thyme & $\begin{array}{l}\text { Thymol } \\
\text { P Cymene }\end{array}$ & 0.02 & 0.10 & $2678-4179$ \\
\hline $\begin{array}{l}\text { Romdhane and } \\
\text { Tizaoui, } 2005 \\
{[13]}\end{array}$ & $\begin{array}{l}\text { J. of Chemical } \\
\text { Technology and } \\
\text { biotechnology }\end{array}$ & Aniseed & Anethol & 0.26 & 0.90 & 7318 \\
\hline Ozek, 2012 [14] & $\begin{array}{l}\text { Record of Natural } \\
\text { Products }\end{array}$ & Laurel & 1.8 cineole & 0.68 & 1.36 & $44,143-88,830$ \\
\hline
\end{tabular}




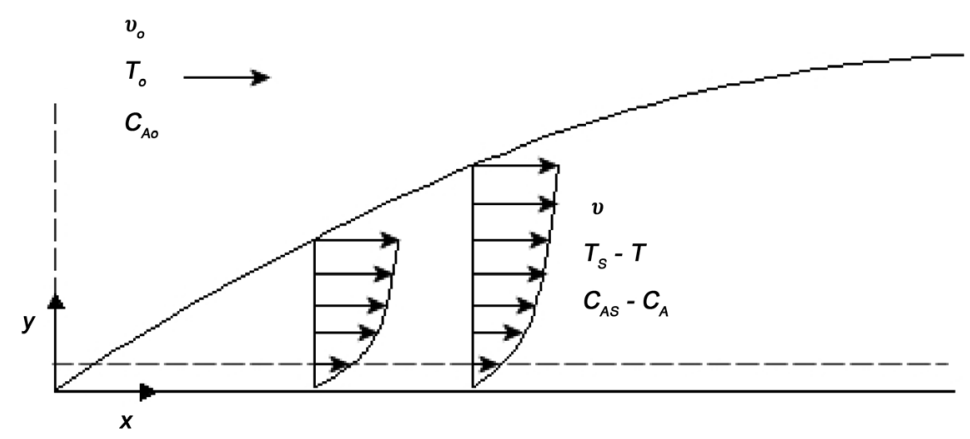

Figure 2. Gradients of velocity, temperature, and concentration at boundary layers.

The continuity equation for $A$, if density $\rho$, and diffusivity $D_{A B}$ are constant, is:

$$
v_{x} \frac{\partial \gamma_{A}}{\partial x}+v_{y} \frac{\partial \gamma_{A}}{\partial y}=D_{A B}\left(\frac{\partial^{2} \gamma_{A}}{\partial y^{2}}\right)
$$

It has as boundary conditions: $\gamma_{A}(x=0, y)=\gamma_{A o} ; \gamma_{A}(x, y=0)=0$; $\gamma_{A}(x, y=\infty)=\gamma_{A o}$

That is similar to the one Blasius solved, but now for mass transfer. The dependent variable is now $\varnothing=\frac{\gamma_{A}}{\gamma_{A o}}=\frac{C_{A i}-C_{A}}{C_{A i}-C_{A o}}$ that is function of the dimensionless variable $\eta=\frac{y}{x} \sqrt{R e_{x}}$.

If it is desired a mathematical expression for the flux of $A$ at the solid surface $\left(N_{A}\right.$ in $\left.\mathrm{kmol} / \mathrm{m}^{2} / \mathrm{s}\right)$, it is needed to use Fick's law to obtain

$$
N_{A, x}=0.332 D_{A B}\left(C_{A i}-C_{A o}\right) \frac{\sqrt{R e_{x}}}{x}
$$

Integrating over the plate length

$$
N_{A}=0.664 \frac{D_{A B}\left(C_{A i}-C_{A o}\right)}{L} \sqrt{R e_{L}}
$$

By analogy to the thermal boundary layer, the Schmidt number relates the diffusivities of mass and momentum, giving:

$$
S C \equiv \frac{v}{D_{A B}}=\frac{\mu}{\rho D_{A B}}
$$

Equation (4) is valid only if $S \mathcal{C}=1$. For the cases with $S \mathcal{C} \neq 1$ it is necessary to introduce an experimental correction factor $S c^{1 / 3}$

$$
N_{A}=0.664 \frac{D_{A B}\left(C_{A i}-C_{A o}\right)}{L} \sqrt{R e_{L}} S c^{1 / 3}
$$

Equation (6) has been experimentally tested.

\subsection{Mass Transfer Coefficient}

Equation (6) allows the calculation of the rate of mass transfer for molecular diffusion at forced convection for laminar flow. If the flow is turbulent or the geome- 
try of the system is complex, as is the case in many practical cases. For this case it is necessary to use the mass transfer coefficient, defined by Equation (7):

$$
k_{c} \equiv \frac{N_{A}}{\Delta C_{A}}=\frac{N_{A}}{C_{A i}-C_{A o}}
$$

Applying Equation (6) on Equation (7) we get:

$$
k_{c}=\frac{0.664 D_{A B} \sqrt{R e_{L}}}{L} S c^{1 / 3}
$$

This equation may be arranged and it provide the Sherwood dimensionless number:

$$
S h=\frac{k_{c} L}{D_{A B}}=0.664 \sqrt{R e_{L}} S c^{1 / 3}
$$

$S h$ is the Sherwood number, counterpart of Nusselt number in heat transfer. At turbulent flow, and for complex geometrical systems the mass transfer coefficient $k_{C}$ will be empirical.

\subsection{Application to Extraction with Steam Flow}

From the reported data with the sources given in Table 1, we may calculate the amount of mass extracted with $m_{\text {extracted }}=m_{o}$ yieldx $100(\mathrm{~kg})$ and convert it to $\mathrm{kmol}$ dividing it between the molecular weight of the solute extracted. Then the flux of $A\left(N_{A}, \mathrm{kmol} / \mathrm{m}^{2} / \mathrm{s}\right)$ will be this $\mathrm{kmol}$ divided between the transversal area to flow and also divided by the residence time of the flow. This last parameter may be calculated dividing the volume $\left(\mathrm{m}^{3}\right)$ of extractor between the volumetric flows of steam $\left(\mathrm{m}^{3} / \mathrm{s}\right)$.

A program was developed with Excel software and applied to each series of data in Table 1. $C_{A i}$ is the concentration of solute at the surface of the vegetal leave (at $y=0$ ). This may be taken as the solubility of the solute in $\mathrm{kmol} / \mathrm{m}^{3}$. Because the steam does not contain solute: $C_{A o}=0$. Then using Equation (7):

$$
k_{c}=\frac{N_{A}}{C_{A i}-C_{A o}}=\frac{\frac{\mathrm{kmol}}{\mathrm{m}^{2} \cdot \mathrm{s}}}{\frac{\mathrm{kmol}}{\mathrm{m}^{3}}}=\frac{\mathrm{m}}{\mathrm{s}}
$$

Then with physical properties, we calculate Sherwood number $\left(k_{c} D / D_{A B}\right)$, and calculating Reynolds number $R e=\frac{U_{e f} \operatorname{den}_{V} D_{C}}{v i s C_{V}}=\frac{\frac{\mathrm{m}}{\mathrm{s}} \cdot \frac{\mathrm{kg}}{\mathrm{m}^{3}} \cdot \mathrm{m}}{\frac{\mathrm{kg}}{\mathrm{m} \cdot \mathrm{s}}}$ and Schmidt number $S C=\frac{\text { visc }}{\operatorname{den} D_{A B}}=\frac{\frac{\mathrm{kg}}{\mathrm{m} \cdot \mathrm{s}}}{\frac{\mathrm{kg}}{\mathrm{m}^{3}} \cdot \frac{\mathrm{m}^{2}}{\mathrm{~s}}}$ and using a reasonable number of data points we can correlate coefficient and exponents $\left(\alpha_{1}, \alpha_{2}\right.$, and $\left.\alpha_{3}\right)$.

\subsection{Physical Properties}

Table 2 shows some of the physical properties used in the Excel program. 
Table 2. Physical properties of solutes that dissolves into steam.

\begin{tabular}{|c|c|c|c|c|c|c|}
\hline Author(s) & Solute & $\begin{array}{l}\text { Density } \\
\left(\mathrm{kg} / \mathrm{m}^{3}\right)\end{array}$ & $\begin{array}{l}\text { Viscosity } \\
(\mathrm{kg} / \mathrm{m} / \mathrm{s})\end{array}$ & $\begin{array}{l}\text { Diffusivity } \\
\left(\mathrm{m}^{2} / \mathrm{s}\right)\end{array}$ & $\begin{array}{l}\text { Molecular } \\
\text { weight } \\
(\mathrm{kg} / \mathrm{kmol})\end{array}$ & $\begin{array}{l}\text { Solubility } \\
\left(\mathrm{kmol} / \mathrm{m}^{3}\right)\end{array}$ \\
\hline $\begin{array}{l}\text { Cerpa et al. 2007, } \\
\quad 2008 \text { [5] [7] }\end{array}$ & $\begin{array}{l}\text { Linalool } \\
\text { and linalyl } \\
\text { acetate }\end{array}$ & 0.555 & $1.32 \mathrm{E}-5$ & $1.10 \mathrm{E}-5$ & 175 & 0.080000 \\
\hline $\begin{array}{l}\text { Masango, } \\
2005 \text { [9] }\end{array}$ & Camphor-L & 0.555 & $1.32 \mathrm{E}-5$ & $1.17 \mathrm{E}-5$ & 152 & 0.080000 \\
\hline $\begin{array}{l}\text { Soto-Armenta } \\
\text { et al. } 2017 \text { [10]. }\end{array}$ & $\begin{array}{l}\text { Carvacrol } \\
\text { and } \\
\text { Thymol }\end{array}$ & 0.555 & $1.32 \mathrm{E}-5$ & $1.18 \mathrm{E}-5$ & 150 & 0.007160 \\
\hline $\begin{array}{l}\text { Malekydozzadeh, } \\
2012 \text { [11] }\end{array}$ & $\begin{array}{c}\text { a-pynene, } \\
1,8 \\
\text { Cineole, } \\
\text { Camphor }\end{array}$ & 0.555 & $1.32 \mathrm{E}-5$ & $1.17 \mathrm{E}-5$ & 152 & 0.007600 \\
\hline $\begin{array}{c}\text { Roautby et al. } \\
2007 \text { [12] }\end{array}$ & $\begin{array}{l}\text { Thymol } \\
\text { P Cymene }\end{array}$ & $\begin{array}{c}0.597 \\
\left(100^{\circ} \mathrm{C}\right) \\
4.515 \\
\left(175^{\circ} \mathrm{C}\right) \\
19.984 \\
\left(250^{\circ} \mathrm{C}\right)\end{array}$ & $\begin{array}{l}1.30 \mathrm{E}-5 \\
1.50 \mathrm{E}-5 \\
1.80 \mathrm{E}-5\end{array}$ & $\begin{array}{l}1.18 \mathrm{E}-5 \\
1.63 \mathrm{E}-5 \\
2.14 \mathrm{E}-5\end{array}$ & 148 & $\begin{array}{l}0.005900 \\
0.005900 \\
0.005900\end{array}$ \\
\hline $\begin{array}{c}\text { Romdhane and } \\
\text { Tizaoui, } 2005 \\
{[13]}\end{array}$ & Anethol & 0.597 & $1.32 \mathrm{E}-5$ & $9.06 \mathrm{E}-6$ & 148 & 0.000750 \\
\hline Ozek, 2012 [14] & 1.8 cineole & 0.555 & $1.32 \mathrm{E}-5$ & $1.16 \mathrm{E}-5$ & 154 & 0.000023 \\
\hline
\end{tabular}

Density and viscosity were taken from [8], diffusivities were predicted withthe correlation of Fuller et al. [15]. Solubility was taken from PubChem, National Library of Medicine, Center for Biotechnology Information, that usually is expressed as $\mathrm{mg}$ or $\mathrm{gr} / \mathrm{liter}$. We convert it to $\mathrm{kg}$ and to kmol dividing between the molecular weight and converting the volume at the denominator to cubic meters.

Most of the experimental extraction with steam used atmospheric pressure and temperature of $100^{\circ} \mathrm{C}$. Only some data from Roautby et al. [12] and Rondhame and Tizaoui [13] were at temperature above $100^{\circ} \mathrm{C}$. These data were processed in a different Excel program, to get the effect of temperature over the yield of extraction.

In the general study, steam at $100^{\circ} \mathrm{C}$ was used and the physical properties density and viscosity keep constant values. Diffusivity varies a little depending of the solute.

The exponent $\alpha_{3}$ in Equation (1) keep a constant value of $1 / 3$ or 0.33 for the Schmidt number in the hydrodynamic bounder layer as well as for the Prandtl thermal boundary. Then, here for mass transfer, we are going to take this exponent constant: $\alpha_{3}=0.33$. 


\section{Results and Discussion}

\subsection{Results from Excel Program for $T=100^{\circ} \mathrm{C}$}

Table 3 shows some of the results of the Excel program applied to the data at $100^{\circ} \mathrm{C}$. It is noted that the Reynolds number is less than unity for the systems of Cerpa et al. and Masango et al., and is bigger for all other systems, reaching values above 2000 for the systems of Roautby et al. and Ozek.

Figure 3 shows the plot of $\operatorname{Ln}\left(S h / S c^{(1 / 3)}\right)$ versus $\operatorname{Ln}\left(R e_{D c}\right)$ obtained when $\alpha_{3}=$ $(1 / 3)$ for all data for the several systems used. From this data, Equation (11) provides the first correlation equation.

$$
S h=\alpha_{1} \operatorname{Re}_{D c}^{\alpha_{2}} S c^{\alpha_{3}}=0.2754 R e_{D c}^{1.5338} S C^{0.333}
$$

If we pass the line at the intersection $S h / S C^{0.33}=1.0$ to get $R e_{D c}=0$, we get the equation $y=1.2964 x+1$ and from this equation we get the second correlation Equation (12). The prediction with Equation (11) and Equation (12) is shown in Figure 4(a) and Figure 4(b). The two correlations may be considered limits for prediction.

$$
S h=\alpha_{1} R e_{D c}^{\alpha_{2}} S c^{\alpha_{3}}=2.7182 R e_{D c}^{1.2964} S c^{0.333}
$$

\subsection{Results for Temperature Increase}

Rouatby et al. [12] studied the extraction of essential oil of thyme by superheated steam. They used steam temperatures of $100^{\circ} \mathrm{C}, 175^{\circ} \mathrm{C}$, and $250^{\circ} \mathrm{C}$. They found that at higher temperatures the yield of extraction increases. Because the physical

\begin{tabular}{|c|c|c|c|c|c|c|c|}
\hline Author(s) & $R e_{D c}$ & $\begin{array}{l}m_{A} \\
\mathrm{~kg}\end{array}$ & $\begin{array}{c}N_{A} \\
\mathrm{kmol} / \mathrm{m}^{2} / \mathrm{s}\end{array}$ & $\begin{array}{c}K_{c} \\
\mathrm{~m} / \mathrm{s}\end{array}$ & $S h_{\alpha 1 \alpha 2} \alpha_{1} \alpha_{2}$ & $S h_{\alpha 1 \alpha 2} \alpha_{1} \alpha_{2}$ & $S h_{\alpha 1 \alpha 2} \alpha_{1} \alpha_{2}$ \\
\hline $\begin{array}{l}\text { Cerpa et al. } \\
2007,2008[5][7]\end{array}$ & $0.032 / 0.124$ & $0.026 / 0.036$ & $\begin{array}{c}6.41 \mathrm{E}-9 / \\
3.09 \mathrm{E}-8\end{array}$ & $\begin{array}{l}8.01 \mathrm{E}-8 / \\
3.86 \mathrm{E}-7\end{array}$ & $\begin{array}{c}2.55 \mathrm{E}-3 / \\
1.23 \mathrm{E}-2\end{array}$ & 0.0801 & 1.0672 \\
\hline Masango, 2005 [9] & $0.035 / 0.274$ & $\begin{array}{c}2.33 \mathrm{E}-4 / \\
7.13 \mathrm{E}-4\end{array}$ & $\begin{array}{l}1.68 \mathrm{E}-8 / \\
4.34 \mathrm{E}-8\end{array}$ & $\begin{array}{c}2.10 \mathrm{E}-7 / \\
5.43 \mathrm{E}-7\end{array}$ & $\begin{array}{l}1.54 \mathrm{E}-3 / \\
3.99 \mathrm{E}-3\end{array}$ & 0.0057 & 0.4547 \\
\hline $\begin{array}{l}\text { Soto-Armenta et al. } \\
2017 \text { [10] }\end{array}$ & $0.288 / 1.440$ & $\begin{array}{c}3.92 \mathrm{E}-3 / \\
9.87 \mathrm{E}-3\end{array}$ & $\begin{array}{c}4.69 \mathrm{E}-7 / \\
1.96 \mathrm{E}-6\end{array}$ & $\begin{array}{c}6.54 \mathrm{E}-5 / \\
2.73 \mathrm{E}-4\end{array}$ & $\begin{array}{l}5.55 \mathrm{E}-1 / \\
2.32 \mathrm{E} 0\end{array}$ & 1.1763 & 0.6177 \\
\hline $\begin{array}{l}\text { Malekydozzadeh, } \\
2012 \text { [11] }\end{array}$ & $79.3 / 178.4$ & $\begin{array}{c}8.30 \mathrm{E}-4 / \\
1.55 \mathrm{E}-3\end{array}$ & $\begin{array}{c}1.26 \mathrm{E}-4 / \\
5.63 \mathrm{E}-4\end{array}$ & $\begin{array}{l}1.65 \mathrm{E}-2 / \\
7.41 \mathrm{E}-2\end{array}$ & $\begin{array}{l}8.48 \mathrm{E} 1 / \\
3.80 \mathrm{E} 2\end{array}$ & 1.0550 & 1.0447 \\
\hline Roautby et al. [12] & $2092.1 / 4525.7$ & $\begin{array}{c}0.000231 / \\
0.000420\end{array}$ & $\begin{array}{l}5.54 \mathrm{E}-3 / \\
2.44 \mathrm{E}-1\end{array}$ & $\begin{array}{l}1.80 / \\
78.6\end{array}$ & $\begin{array}{c}1671.4 / \\
133,160.6\end{array}$ & 1.5600 & 1.2265 \\
\hline $\begin{array}{l}\text { Romdhane and } \\
\text { Tizaoui [13] }\end{array}$ & $787.7 / 812.4$ & $0.036 / 0.098$ & $\begin{array}{l}1.51 \mathrm{E}-4 / \\
3.51 \mathrm{E}-4\end{array}$ & $\begin{array}{c}2.02 \mathrm{E}-1 / \\
4.69 \mathrm{E}-1\end{array}$ & $\begin{array}{l}6.99 \mathrm{E} 3 / \\
1.88 \mathrm{E} 4\end{array}$ & 0.3470 & 1.3527 \\
\hline Ozek, 2012 [14] & $1287.1 / 2590.1$ & $0.350 / 1.380$ & $\begin{array}{c}2.73 \mathrm{E}-4 / \\
8.06 \mathrm{E}-4\end{array}$ & $12.0 / 35.5$ & $\begin{array}{l}7.04 \mathrm{E} 5 / \\
2.08 \mathrm{E} 6\end{array}$ & 1.201 & 1.8199 \\
\hline All prediction 1 & $0.032 / 4525.7$ & $\begin{array}{c}2.31 \mathrm{E}-4 / \\
1.38 \mathrm{E} 0\end{array}$ & $\begin{array}{l}6.41 \mathrm{E}-9 / \\
2.33 \mathrm{E}-1\end{array}$ & $\begin{array}{c}8.01 \mathrm{E}-8 / \\
3.96 \mathrm{E} 1\end{array}$ & $\begin{array}{c}1.54 \mathrm{E}-3 / \\
2.08 \mathrm{E} 6\end{array}$ & 0.2752 & 1.5338 \\
\hline All prediction 2 & $0.032 / 4525.7$ & $\begin{array}{c}2.31 \mathrm{E}-4 / \\
1.38 \mathrm{E} 0\end{array}$ & $\begin{array}{l}6.41 \mathrm{E}-9 / \\
2.33 \mathrm{E}-1\end{array}$ & $\begin{array}{c}8.01 \mathrm{E}-8 / \\
3.96 \mathrm{E} 1\end{array}$ & $\begin{array}{c}1.54 \mathrm{E}-3 / \\
2.08 \mathrm{E} 6\end{array}$ & 2.7182 & 1.2964 \\
\hline
\end{tabular}

Table 3. Parameters and mass transfer coefficient and exponent, from correlated data, for $\alpha_{3}=1 / 3$. 


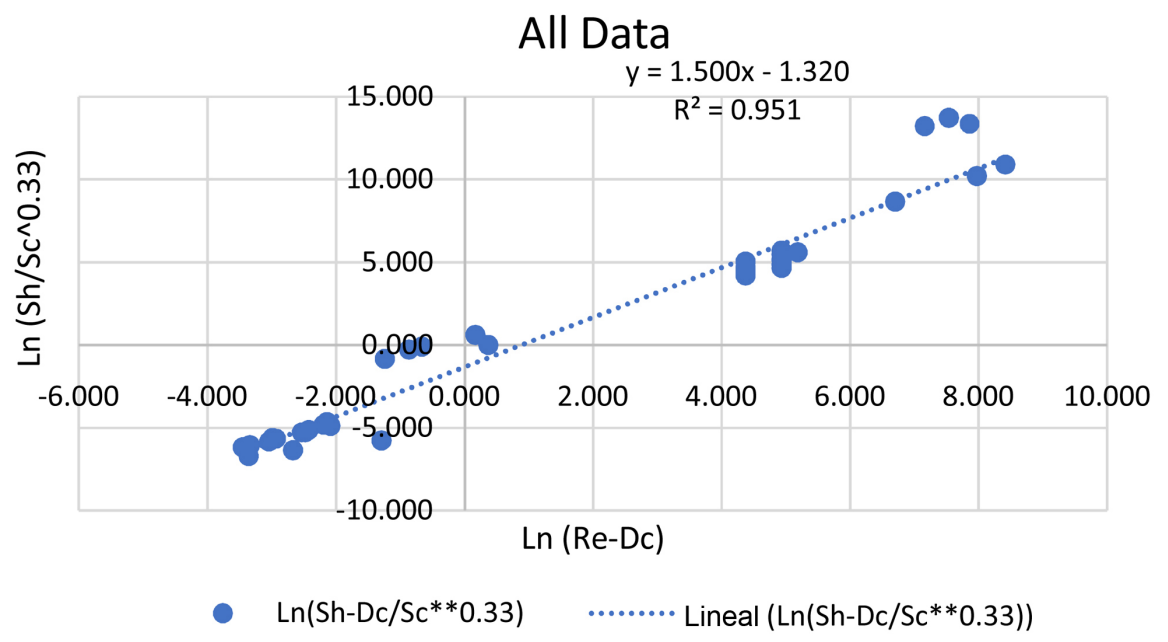

Figure 3. $\operatorname{Ln}(R e)$ versus $\operatorname{Ln}\left(S h / S c^{0.33}\right)$ used to get $\alpha_{1}$ and $\alpha_{2}$.

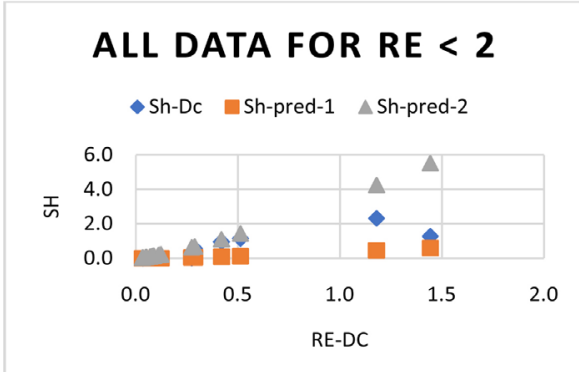

(a)

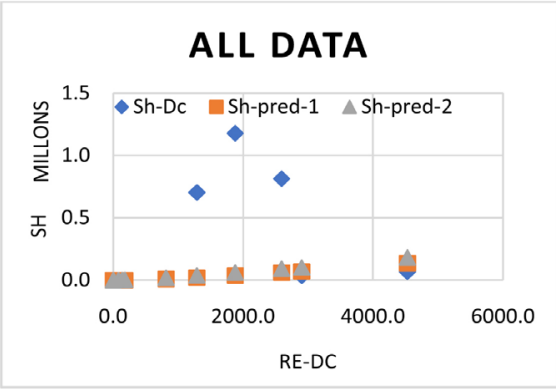

(b)

Figure 4. Prediction of Sherwood number for all data. (a) For RE < 2, (b) ALL DATA.

properties changed, most of the parameters changed as well. Table 4 shows some of the values obtained.

The last two rows of Table 4 provide the ratio of the property or parameter at $175^{\circ} \mathrm{C} / 100^{\circ} \mathrm{C}$, and $250^{\circ} \mathrm{C} / 100^{\circ} \mathrm{C}$. When that ratio is unity, the values are similar for the three temperatures.

When the ratio is fractional, by example the volumetric flow of steam: $\frac{Q_{175}}{Q_{100}}=0.132$ means that the volumetric flow rate of steam at $175^{\circ} \mathrm{C}$ is 0.132 times the volumetric flow rate at $100^{\circ} \mathrm{C}$. This happen because the density of steam at $175^{\circ} \mathrm{C}$ is 7.56 times higher than at $100^{\circ} \mathrm{C}$.

For the flow at $250^{\circ} \mathrm{C}$ the ratio is $\frac{Q_{250}}{Q_{100}}=0.030$ this means that the flow rate of steam at $250^{\circ} \mathrm{C}$ is about $3 \%$ of the volumetric flow rate of steam at $100^{\circ} \mathrm{C}$.

When the ratio is higher than unity, by example $\frac{Y_{175}}{Y_{100}}=1.205$ this means that the yield of extraction is 1.205 higher at $175^{\circ} \mathrm{C}$ than at $100^{\circ} \mathrm{C}$.

Note that the superficial and effective velocities are higher at low temperatures $\left(100^{\circ} \mathrm{C}\right)$ than at $175^{\circ} \mathrm{C}$ or $250^{\circ} \mathrm{C}$, residence time, density, viscosity, diffusivity, and the mass extracted are higher for bigger temperatures. Reynolds, Schmidt, 
Table 4. Some values for Data of Roautby et al. [12] for the extraction of thyme leaves.

(a)

\begin{tabular}{lcccccccc}
\hline \multirow{2}{*}{ Roautby et al. [12] } & $\mathrm{min}$ & $\mathrm{sec}$ & $\mathrm{m}$ & $\mathrm{m}$ & $\mathrm{m}^{3} / \mathrm{m}^{3}$ & $\mathrm{~kg}$ & $\mathrm{~m} / \mathrm{s}$ & $\%$ \\
\cline { 2 - 8 } & $t_{\min }$ & $t$ & $D_{c}$ & $Z$ & $E$ & $M_{o}$ & $Q$ & $Y$ \\
\hline$m=1.6 \mathrm{k} / \mathrm{h}, Q=0.000744,100^{\circ} \mathrm{C}$ & 40.0 & 2400.00 & 0.020000 & 0.10 & 0.750 & 0.007 & 0.000744 & 3.30 \\
$m=2.5, Q=0.001163,100^{\circ} \mathrm{C}$ & 40.0 & 2400.00 & 0.020000 & 0.10 & 0.750 & 0.007 & 0.001161 & 4.20 \\
$m=1.6 \mathrm{k} / \mathrm{h}, Q=0.000098,175^{\circ} \mathrm{C}$ & 40.0 & 2400.00 & 0.020000 & 0.10 & 0.750 & 0.007 & 0.000098 & 4.10 \\
$m=2.5, Q=0.000153,175^{\circ} \mathrm{C}$ & 40.0 & 2400.00 & 0.020000 & 0.10 & 0.750 & 0.007 & 0.000153 & 4.90 \\
$m=1.6 \mathrm{k} / \mathrm{h}, Q=0.000022,250^{\circ} \mathrm{C}$ & 40.0 & 2400.00 & 0.020000 & 0.10 & 0.750 & 0.007 & 0.000022 & 5.00 \\
$m=2.5, Q=0.000034,250^{\circ} \mathrm{C}$ & 40.0 & 2400.00 & 0.020000 & 0.10 & 0.750 & 0.007 & 0.000034 & 6.00 \\
$X_{5} / X_{3}$ & 1.000 & 1.000 & 1.000 & 1.000 & 1.000 & 1.000 & 0.132 & 1.242 \\
$X_{7} / X_{3}$ & 1.000 & 1.000 & 1.000 & 1.000 & 1.000 & 1.000 & 0.030 & 1.515 \\
$X_{6} / X_{4}$ & 1.000 & 1.000 & 1.000 & 1.000 & 1.000 & 1.000 & 0.132 & 1.167 \\
$X_{8} / X_{4}$ & 1.000 & 1.000 & 1.000 & 1.000 & 1.000 & 1.000 & 0.029 & 1.429 \\
$\left(X_{5} / X_{3}+X_{7} / X_{3}\right) / 2$ & 1.000 & 1.000 & 1.000 & 1.000 & 1.000 & 1.000 & 0.132 & 1.205 \\
$\left(X_{6} / X_{4}+X_{8} / X_{4}\right) / 2$ & 1.000 & 1.000 & 1.000 & 1.000 & 1.000 & 1.000 & 0.030 & 1.472 \\
\hline
\end{tabular}

(b)

\begin{tabular}{ccccccccccc}
\hline $\mathrm{m}^{2}$ & $\mathrm{~m}^{3}$ & $\mathrm{~m} / \mathrm{s}$ & $\mathrm{m} / \mathrm{s}$ & $\mathrm{s}$ & $\mathrm{kg} / \mathrm{m}^{3}$ & $\mathrm{~kg} / \mathrm{m} / \mathrm{s}$ & $\mathrm{m}^{2} / \mathrm{s}$ & $\mathrm{kg} / \mathrm{kmol}$ & $\mathrm{kmol} / \mathrm{m}^{3}$ \\
\hline $\mathrm{A}$ & $\mathrm{V}$ & $\mathrm{Us}$ & $\mathrm{Uef}$ & $\mathrm{tR}$ & $\mathrm{den}$ & $\mathrm{vis}$ & $\mathrm{DAB}$ & PMA & Cai-solub \\
\hline 0.000314 & 0.000031 & 2.368220 & 3.157627 & 0.042 & 0.597 & $1.30 \mathrm{E}-05$ & $1.18 \mathrm{E}-05$ & $1.42 \mathrm{E}+02$ & 0.003 \\
0.000314 & 0.000031 & 3.695569 & 4.927426 & 0.027 & 0.597 & $1.30 \mathrm{E}-05$ & $1.18 \mathrm{E}-05$ & $1.42 \mathrm{E}+02$ & 0.003 \\
0.000314 & 0.000031 & 0.313216 & 0.417622 & 0.319 & 4.515 & $1.50 \mathrm{E}-05$ & $1.63 \mathrm{E}-05$ & $1.42 \mathrm{E}+02$ & 0.003 \\
0.000314 & 0.000031 & 0.487013 & 0.649351 & 0.205 & 4.515 & $1.50 \mathrm{E}-05$ & $1.63 \mathrm{E}-05$ & $1.42 \mathrm{E}+02$ & 0.003 \\
0.000314 & 0.000031 & 0.070665 & 0.094220 & 1.415 & 19.984 & $1.80 \mathrm{E}-05$ & $2.14 \mathrm{E}-05$ & $1.42 \mathrm{E}+02$ & 0.003 \\
0.000314 & 0.000031 & 0.108225 & 0.144300 & 0.924 & 19.984 & $1.80 \mathrm{E}-05$ & $2.14 \mathrm{E}-05$ & $1.42 \mathrm{E}+02$ & 0.003 \\
1.000 & 1.000 & 0.132 & 0.132 & 7.561 & 7.563 & 1.154 & 1.381 & 1.000 & 1.000 \\
1.000 & 1.000 & 0.030 & 0.030 & 33.514 & 33.474 & 1.385 & 1.814 & 1.000 & 1.000 \\
1.000 & 1.000 & 0.132 & 0.132 & 7.588 & 7.563 & 1.154 & 1.381 & 1.000 & 1.000 \\
1.000 & 1.000 & 0.029 & 0.029 & 34.147 & 33.474 & 1.385 & 1.814 & 1.000 & 1.000 \\
1.000 & 1.000 & 0.132 & 0.132 & 7.575 & 7.563 & 1.154 & 1.381 & 1.000 & 1.000 \\
1.000 & 1.000 & 0.030 & 0.030 & 33.830 & 33.474 & 1.385 & 1.814 & 1.000 & 1.000 \\
\hline
\end{tabular}

(c)

\begin{tabular}{|c|c|c|c|c|c|c|c|}
\hline $\mathrm{U}^{\star} \mathrm{den}^{\star} \mathrm{Dc} / \mathrm{vis}$ & den $^{\star}$ vis/DAB & $\mathrm{kg}$ & $\mathrm{kmol} / \mathrm{m}^{2} / \mathrm{s}$ & $\mathrm{m} / \mathrm{s}$ & $\mathrm{Kc}^{\star} \mathrm{Dc} / \mathrm{DAB}$ & & Roautby et al [12] \\
\hline Re-Dc & $\mathrm{Sc}$ & $\mathrm{mA}$ & NA & Kc & Sh-Dc & Sh-Dc-p1 & 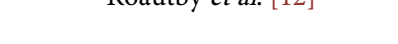 \\
\hline 2900.16 & 1.845 & 0.000231 & 0.123 & 39.56 & $67,047.3$ & $21,248.9$ & $m=1.6 \mathrm{k} / \mathrm{h}, Q=0.000744,100^{\circ} \mathrm{C}$ \\
\hline 4525.65 & 1.845 & 0.000294 & 0.244 & 78.56 & $133,160.6$ & $84,452.8$ & $m=2.5, Q=0.001163,100^{\circ} \mathrm{C}$ \\
\hline 2514.08 & 0.204 & 0.000287 & 0.020 & 6.50 & 7975.7 & 6546.4 & $m=1.6 \mathrm{k} / \mathrm{h}, Q=0.000098,175^{\circ} \mathrm{C}$ \\
\hline 3909.09 & 0.204 & 0.000343 & 0.037 & 12.08 & $14,821.0$ & $25,729.6$ & $m=2.5, Q=0.000153,175^{\circ} \mathrm{C}$ \\
\hline 2092.09 & 0.042 & 0.000350 & 0.006 & 1.79 & 1671.4 & 2188.8 & $m=1.6 \mathrm{k} / \mathrm{h}, Q=0.000022,250^{\circ} \mathrm{C}$ \\
\hline 3204.10 & 0.042 & 0.000420 & 0.010 & 3.29 & 3071.8 & 8208.3 & $m=2.5, Q=0.000034,250^{\circ} \mathrm{C}$ \\
\hline 0.867 & 0.110 & 1.242 & 0.164 & 0.164 & 0.119 & 0.308 & $x_{5} / x_{3}$ \\
\hline 0.721 & 0.023 & 1.515 & 0.045 & 0.045 & 0.025 & 0.103 & $x_{7} / x_{3}$ \\
\hline 0.864 & 0.110 & 1.167 & 0.154 & 0.154 & 0.111 & 0.305 & $x_{6} / X_{4}$ \\
\hline 0.708 & 0.023 & 1.429 & 0.042 & 0.042 & 0.023 & 0.097 & $x_{8} / x_{4}$ \\
\hline 0.865 & 0.110 & 1.205 & 0.159 & 0.159 & 0.115 & 0.306 & $\left(x_{5} / x_{3}+x_{7} / x_{3}\right) / 2$ \\
\hline 0.715 & 0.023 & 1.472 & 0.044 & 0.044 & 0.024 & 0.100 & $\left(X_{6} / X_{4}+X_{8} / X_{4}\right) / 2$ \\
\hline
\end{tabular}


and Sherwood numbers, as well as the molar flux and the mass transfer coefficient are lower for the higher temperatures. For predicted Sherwood number:

$$
\begin{aligned}
& \frac{S h_{175}}{S h_{100}}=0.306 \\
& \frac{S h_{250}}{S h_{100}}=0.100
\end{aligned}
$$

Figure 5 provides a method to estimate the Sherwood number at different temperatures of steam.

\section{Case of Study, Prediction of Yield}

The data on the paper of Koul et al. [16] will be taken as example to predict the yield of experiments $3,4,5,6$, and 7 . In this case lemon grass oil is obtained by steam distillation of lemon grass (Cymbopogon spp.) the main solute is citral or geranial $\left(\mathrm{C}_{10} \mathrm{H}_{16} \mathrm{O}\right)$, that has the same formula than camphor then $\left(D_{A B}=\right.$ $1.17 \mathrm{E}-5 \mathrm{~m}^{2} / \mathrm{s}$ ) but the solubility is $C_{A i}=0.003289 \mathrm{kmol} / \mathrm{m}^{3}$.

The first two experiments used $m_{o}=70 \mathrm{~kg}$, and the last three used $1000 \mathrm{~kg}$. These are industrial quantities. In Table 1 the data of Ozek use the biggest equipment size $\left(0.5 \mathrm{~m}^{3}\right)$ and the highest quantity of vegetal leaves $(24-38 \mathrm{~kg})$. We era going to use the data of Ozek to estimate the volume of cylinder needed for Koul experiments. Ozek [14] used $V=0.5 \mathrm{~m}^{3}$ for $35 \mathrm{~kg}$ of mass. Then for Koul:

$$
V_{1}=0.5 \times 100 / 35=1.428 \mathrm{~m}^{3} \text { and } V_{2}=0.5 \times 1000 / 35=14.286 \mathrm{~m}^{3}
$$

Choosing a diameter of $D c=2.0 \mathrm{~m}, A=3.1416^{*} D c^{2} / 4=3.1416 \mathrm{~m}^{2}$, and $V=$ $A^{\star} Z$, then $Z_{1}=V_{1} / A=1.428 / 3.1416=0.46 \mathrm{~m}=Z_{1}$, and $z_{2}=V_{2} / A=14.286 / 3.1416=$ $4.55 \mathrm{~m}=Z_{2}$.

The steam flow rate $Q_{i}$ in $\mathrm{m}^{3} / \mathrm{s}$ used in Koul experiments were: 15, 12, 160, 125 and $140 \mathrm{~L} / \mathrm{h}\left(0.015,0.012,0.125,0.140 \mathrm{~m}^{3} / \mathrm{h}\right.$, or $4.166 \mathrm{E}-6,3.33 \mathrm{E}-6,4.44 \mathrm{E}-5$, $\left.3.472 \mathrm{E}-5,3.88 \mathrm{E}-5 \mathrm{~m}^{3} / \mathrm{s}\right)$.

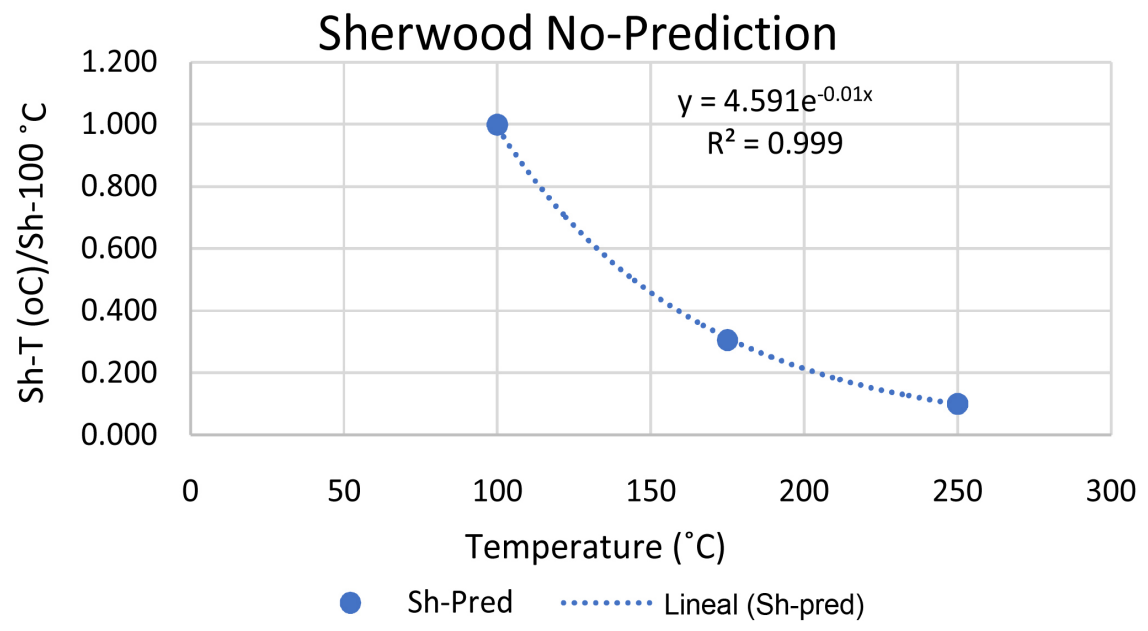

Figure 5. Prediction for temperature of steam effect on Sherwood number. 
For the yield calculation, experiments 3 - 7 were: 385, 330, 5725, 5215, 5315 $\mathrm{mL}$ of citral oil at $5 \mathrm{~h}=300$ minutes $=18,000$ seconds. With a density of citral of $0.9 \mathrm{gr} / \mathrm{ml}$ or $900 \mathrm{~kg} / \mathrm{m}^{3}$ and the $70 \mathrm{~kg}$ of lemon grass for experiments 3 and 4 and $1000 \mathrm{~kg}$ of lemon grass for experiments $5-7$, we get: $y_{3}=0.495, y_{4}=0.424, y_{5}=$ $0.515, y_{6}=0.469, y_{7}=0.478$.

With the cylinder dimensions $D c=2 \mathrm{~m} \mathrm{y} z_{1}=0.46$, and $z_{2}=4.55 \mathrm{~m}$, we get $A=$ $p r^{*} D c^{2} / 4=3.1416 \mathrm{~m}^{2}$, and $V_{1}=1.44 \mathrm{~m}^{3}, V_{2}=14.2 \mathrm{~m}^{3}$. Dividing volumetric flow rate between area we get Superficial velocities, and dividing these between void fraction, we get effective velocities $U_{e ß 3}=0.0000018, U_{e f 4}=0.0000014, U_{e f 5}=$ $0.0000188, U_{\text {eff }}=0.0000147, U_{\text {eff }}=0.0000165 \mathrm{~m} / \mathrm{s}$.

Residence time of steam may be calculated dividing volume between steam volumetric flow rate, and we get: $t_{r 3}=346,888.1, t_{r 4}=433,974.8, t_{r 5}=321,943.2$, $t_{r 6}=411,701.6, t_{r 7}=368,409.3$ seconds.

Now, we can calculate Reynolds numbers with Equation (15)

$$
R e_{i}=\frac{U_{e f i} \operatorname{den}_{v a p} D_{c}}{\operatorname{Visc}_{\text {vap }}}
$$

And Schmidt and Sherwood numbers with Equation (16) and Equation (11) or Equation (12)

$$
S C=\frac{\operatorname{visc}_{v a p}}{\operatorname{den}_{v a p} D_{A B}}
$$

Table 5. Calculated values for Kaoul et al. [16] yields.

\begin{tabular}{ccccccccccc}
\hline & $R e$ & $k_{C 1}$ & $k_{C 2}$ & $N_{A 1}$ & $N_{A 2}$ & $m_{A 1}$ & $m_{A 2}$ & $y_{A p-1}$ & $y_{A p-2}$ & $y_{A-\operatorname{Exp}}$ \\
\hline $\mathrm{E}-3$ & 0.15 & $1.098 \mathrm{E}-07$ & $3.545 \mathrm{E}-06$ & $3.610 \mathrm{E}-08$ & $5.601 \mathrm{E}-09$ & 0.060 & 0.929 & 0.09 & 1.33 & 0.50 \\
$\mathrm{E}-4$ & 0.12 & $7.785 \mathrm{E}-08$ & $2.652 \mathrm{E}-06$ & $2.561 \mathrm{E}-10$ & $4.189 \mathrm{E}-09$ & 0.053 & 0.869 & 0.08 & 1.24 & 0.42 \\
$\mathrm{E}-5$ & 1.58 & $4.137 \mathrm{E}-06$ & $7.619 \mathrm{E}-05$ & $1.361 \mathrm{E}-08$ & $1.204 \mathrm{E}-07$ & 2.095 & 18.533 & 0.21 & 1.85 & 0.52 \\
$\mathrm{E}-6$ & 1.24 & $2.837 \mathrm{E}-06$ & $5.539 \mathrm{E}-05$ & $9.332 \mathrm{E}-09$ & $8.751 \mathrm{E}-08$ & 1.837 & 17.230 & 0.18 & 1.72 & 0.47 \\
$\mathrm{E}-7$ & 1.38 & $3.364 \mathrm{E}-06$ & $6.397 \mathrm{E}-05$ & $1.107 \mathrm{E}-07$ & $1.011 \mathrm{E}-07$ & 1.950 & 17.807 & 0.19 & 1.78 & 0.48
\end{tabular}

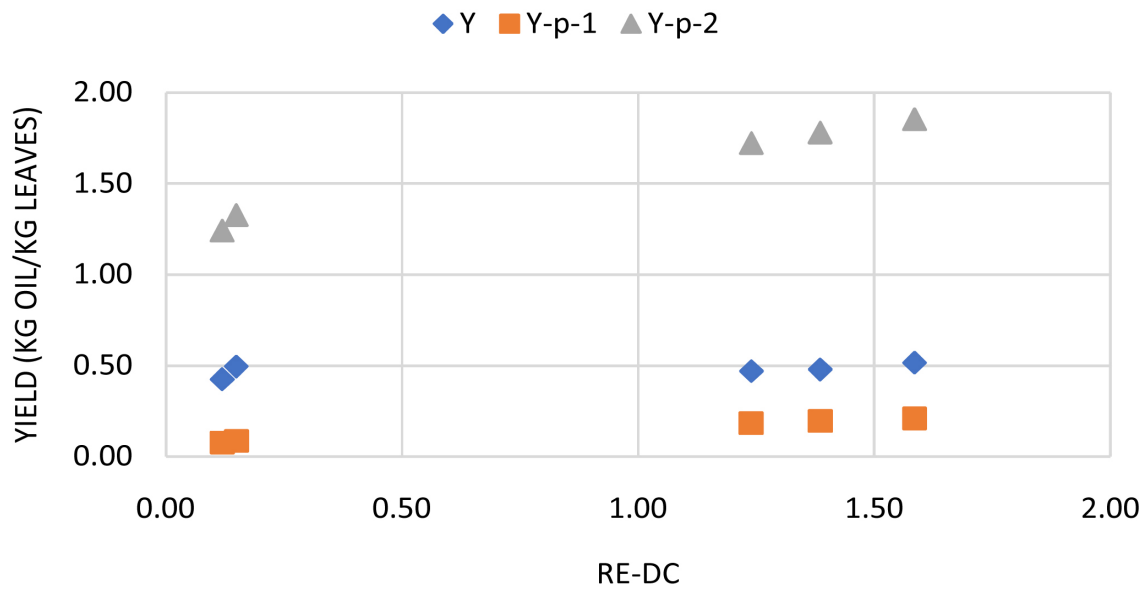

Figure 6. Prediction on Koul [16], using the present model. 
With Sherwood number, we can get the mass transfer coefficient $k_{c}$ and from this, the flux $N_{A}$, then, $m_{A}$, and finally the yield $y_{A}$ with Equations (17)-(20). Because the steam does not have solute $C_{A o}=0$

$$
\begin{gathered}
k_{C}=\frac{S h D_{A B}}{D_{C}} \\
N_{A}=k_{c}\left(C_{A i}-C_{A o}\right) \\
m_{A}=N_{A} \times A \times t_{R} \times P M_{A} \\
y_{a i}=\left(\frac{m_{A}}{m_{o}}\right) \times 100
\end{gathered}
$$

Table 5 provides the main calculated values, and Figure 6 provides the comparison between reported and predicted values.

On Figure 6 it is observed that both predictions 1 and 2 follow the order of the reported data. Prediction 1 underpredicts 0.31 , and prediction 2 overpredicts 3.32 the values of reported yield of extraction from Koul et al. [16].

\section{Conclusions}

The proposed Equation (11) and Equation (12) provide correlations to predict the yield of extraction, by first estimating the dimensionless numbers Reynolds, Schmidt, and Sherwood numbers, and using equations for the mass transfer involved in the extraction of solute from vegetable leaves to steam, using boundary layer concepts and definitions like molar flux and mass transfer coefficient.

The predicting Equation (11) and Equation (12) provide limits to experimental or reported yields and predict well the effect of steam flow.

Figure 5 and Equation (21) help to predict Sherwood number for superheated steam at temperatures above $100^{\circ} \mathrm{C}$.

$$
\frac{\operatorname{Sh}\left(T^{\circ} \mathrm{C}\right)}{\operatorname{Sh}\left(100^{\circ} \mathrm{C}\right)}=4.591 \exp ^{-0.015 \times T\left({ }^{\circ} \mathrm{C}\right)}
$$

Using steam at temperatures higher than $100^{\circ} \mathrm{C}$ improves the extraction yield, but at temperatures above $200^{\circ} \mathrm{C}$, the temperature degrades some components of the mixture of essential oil.

\section{Conflicts of Interest}

The authors declare no conflicts of interest regarding the publication of this paper.

\section{References}

[1] Husar, E., Dzieciol, M., Wodnicka, A., Orun, H., Koz, A. and Cicek, E. (2018) Influence of Hydrodistillation conditions on Yield and Composition of Coriander (Coriandrum sativum L.) essential Oil. Polish Journal of Food and Nutrition Sciences, 68, 243-249. https://doi.org/10.1515/pjfns-2018-0003

[2] Geramitcioski, T., Mitievski, V. and Mijakovski, V. (2018) Design of a Small Press for Extracting Essential Oil According VDI 2221. IOP Conference Series: Materials 
Science and Engineering, 393, Article No. 012131. https://doi.org/10.1088/1757-899X/393/1/012131

[3] Gopalasatheeskumar, K. (2018) Significant Role of Soxhlet Extraction Process in Phytochemical Research. Mintaje Journal of Pharmaceutical \& Medical Sciences, 7, 43-47.

[4] Bagade, S.B. and Patil, M. (2021) Recent Advances in Microwave Assisted Extraction of Bioactive Compounds from Complex Herbal Samples: A Review. Critical Reviews in Analytical Chemistry, 51, 138-149.

https://doi.org/10.1080/10408347.2019.1686966

[5] Cerpa-Chavez, M.G. (2007) Hidrodestillacion de aceites esenciales, Modelado y caracterización. Ph. D. Dissertation, Universidad de Valladolid, Spain.

[6] Xavier, V.B., Vargas, R.M.F., Cassel, E., Lucas, A.M., Santos, M.A., Mondinc, C.A., Santaremc, E.R., Astarita, L.V. and Sartor, T. (2011) Mathematical Modeling for Extraction of Essential Oil from Baccharis spp. by Steam Distillation. Industrial Crops and Products, 33, 599-604. https://doi.org/10.1016/j.indcrop.2010.12.019

[7] Cerpa, M.G., Mato, R.B. and Cocero, M.J. (2008) Modeling Steam Distillation of Essential Oils: Application to Lavandin Super Oil. AIChE Journal, 54, 909-917. https://doi.org/10.1002/aic.11438

[8] Donde-Castro, M., Rocha-Uribe, J. A. and Sacramento-Rivero J. C. (2013) Transferencia de Masa, Teoria y aplicaciones en procesos químicos, Pearson, 2013.

[9] Masango, P. (2005) Cleaner Production of Essential Oils by Steam Distillation. Journal of Cleaner Production, 13, 833-839.

https://doi.org/10.1016/j.jclepro.2004.02.039

[10] Soto-Armenta, L.C., Sacramento-Rivero, J.C., Acereto-Escoffie, P.O., Peraza-Gonzalez, E.E., Reyes-Sosa, C.F. and Rocha-Uribe, J.A. (2017) Extraction Yield of essential Oil from Lippia graveolens Leaves by Steam Distillation at Laboratory and Pilot Scales. Journal of Essential Oils Bearing Plants, 20, 610-621. https://doi.org/10.1080/0972060X.2017.1331756

[11] Malekydozzadeh, M., Khavid-Parsi, P., Rezazadeh, Sh., Abolghasemi, H., Salehi, Z. and Li, Q. (2012) Application of Multistage Steam Distillation Column for Extraction of Essential Oil of Rosemarinuse officinialis L. Iranian Journal of Chemical Engineering, 9, 54-64.

[12] Rouatbi, M., Duquenoy, A. and Giampaoli, P. (2007) Extraction of the Essential Oil of Thyme and Black Pepper by Superheated Steam. Journal of Food Engineering, 78, 708-714. https://doi.org/10.1016/j.jfoodeng.2005.11.010

[13] Romdhane, M. and Tizaoui, C. (2005) The Kinetic Modelling of a Steam Distillation Unit for the Extraction of Aniseed (Pimpinella anisum) Essential Oil. Journal of Chemical Technology and Biotechnology, 80, 759-766. https://doi.org/10.1002/jctb.1221

[14] Özek, T. (2012) Distillation for Pilot Plant Production of Laurus novilis Essential Oil. Journal of Records of Natural Products, 6, 135-143.

[15] Fuller, E.N., Schettler, P.D. and Giddings, J.C. (1966) New Method for Prediction of Binary Gas-Phase Diffusion Coefficients. Industrial \& Engineering Chemistry Research, 58, 18-27. https://doi.org/10.1021/ie50677a007

[16] Koul, V.K., Gandotra, B.M., Koul, S., Ghosh, S., Tikoo, C.L. and Gupta, A.K. (2004) Steam Distillation of Lemon Grass (Cymbopogon spp.). Indian Journal of Chemical Technology, 11, 135-139. 